\title{
STUDY OF LEGAL PHENOMENCES IN SOCIETY FROM THE PERSPECTIVE OF LEGAL RELATIONS AND POWERS
}

\author{
Hasanal Mulkan ${ }^{1}$
}

\begin{abstract}
The type of research used is normative research, legal research which is carried out by examining library materials that use the object of writing studies such as existing libraries, books, magazines, and regulations that have a correlation in problem discussion, so this writing is also writing library (library research). Various legal facts show the existence of power possessed by the state which does not aim to provide justice for society, whereas as it is known that the state is given power by the society on the basis of an agreement (social contract) in order to provide legal protection in the form of justice, one of them is reflected in the case of farmer mistreatment in Mesuji, Lampung due to seizure of land. Because the society feels that they do not get maximum justice as the goal of law in legal philosophy, so then the society can reclaim the power they have given to the authority. As for the basis used by the community in reclaiming the power they have given to the authority, because in the concept of "pactum subjectionis", society has formed an agreement as to who deserves to hold power. After the agreement is made, the powers given to the state are legitimated by using social facts and laws.
\end{abstract}

Keywords: Law, Power, Society.

\section{The Introduction}

Since being born in the world, humans have interacted with other humans in a place called society. Relations between fellow humans and humans with society or their group are arranged by a series of values and principles, that behavior is increasingly institutionalized into patterns. Furthermore, the rule of law takes the form of written regulations, decisions of social institutions. Sociologically, law is important and is a social institution that is a collection of values, rules and patterns of behavior that revolve around basic human needs. This shows that when it is examined in the reality in society that the law regulates almost all aspects of society life (Chomziah,2004:34-35).

From the point of view of political science, law is an instrument of elite power and a little more used as a tool to maintain its power or to increase and develop it. The pros and cons of power depend on how that power is used. This means that the pros and cons of power are always measured by their use in achieving the goals that have been determined or realized by the society in advance(Rasyidi, 1990:78). MaxWeber in his book Wirtschaft und Gesselchaft defines that power as the ability to be in a social relationship, to carry out one's own will even though experiencing resistance and whatever the basis of this ability. This is reinforced by the thoughts of Harold D. Laswell and Abraham Kaplan that the define of power is a relationship where a person or group of people can determine the actions of a person or other group towards the goals of the first party.

Fakultas Hukum Universitas hasanal_mulkan@yahoo.co.id

Muhammadiyah Palembang, Email: 
The relationship between law and power can be briefly formulated in the following slogans: "Law without power is wishful thinking, power without law is tyranny. In its application, the law requires a power to support it. This power is needed because the law is coercive. Without the existence of power, law enforcement in society will experience obstacles. Between law and power there is a close relationship. Lili Rasjidi explained that legal law in its implementation requires the power to support it. This power is needed because the law is coercive, without the power to implement the law it will be hampered (Rasyidi, 2007:90)

In Van Apeldoorn's view, law itself is powerLaw is one source of power, in addition to other sources such as strength (physical and economic), authority (spiritual, intelligence, and moral). In addition, law is a limitation for power, because usually that power has a bad character, which is to always stimulate the holder to want to have power that exceeds what he already has. On this basis Soerjono Soekanto expressed that the merits of a power really depend on how that power is used.

Peperzak states that this relationship can be demonstrated in two ways:

a. Examines from the concept of sanctions

The existence of behavior that does not comply with legal rules causes sanctions to enforce these legal rules. Because the sanction is in fact a form of violence, its use requires juridical legitimacy (legal justification) in order to make it legal violence. In order for sanctions to function properly so that all legal systems can be effective and successful, it is necessary to have powers that provide personnel support and protection for the legal system along with sanctions.

b. Examines from the concept of constitutional enforcement

The development of an orderly system of legal rules in a country is regulated by the law itself. This matter is usually stated in the constitution of the country concerned. Upholding of the constitution, including enforcing correctly procedures in law enforcement, assumes the use of force. Force is needed as a support and protector for the system of legal rules for the sake of enforcement, it means that in the end, the law must be supported and protected by an element that is not legal, namely power.

Even though law has a very close relationship with power, the study of power from a legal perspective is still limited so that the concepts of power in the science of law are not so developed (Abdurrahman,1978:45). The tendency of legal studies is more focused on two aspects: first, law is seen as a rule that becomes a guideline for coercive behavior and imposes sanctions on those who violate it, and secondly, law is seen as a social reality that occurs in society which is practiced through the judiciary (the living law), the existence of law violations (unlawful behavior), and obedience to the law. In short, law contains two main points, they are the rules that should be carried out (das sollen), and the reality that exists in society (das sein) (Soekanto,1980:12). However, in reality only living law and lawlessness have been studied a lot, while obedience to the law is not seen as a problem. This paper intends to examine the dialectical relationship between law and power. The main issues that will be discussed include: how is power in the context of law, how is the 
dialectical relationship between law and power, and what is the function of power over law and the function of law against power (Soetiksno,2008:56).

\section{Research methods}

The type of research used is normative research, legal research which is carried out by examining library materials that use the object of writing studies such as existing libraries, books, magazines, and regulations that have a correlation in problem discussion, so this writing is also writing library (library research).

\section{Discussion and Results}

The state, in running its government, gets power from the society based on the concept of a social contract. Thomas Hobbes in his book "De Cive" and "Leviathan" gave his opinion regarding the theory of community agreement stating that in the beginning humans lived in an atmosphere belum omnium contra omnes (the war of all against all), always in a state of war. In order to create an atmosphere of peace and serenity, an agreement was made between them (pactum unions) after that followed by an agreement between all with a certain person (pactum subjectionis) who will be entrusted with the power to lead them. The power of this leader is absolute. The absolute power arose (Soekanto,2006:87).

It is hoped that the power given by society to the state can create an orderly and normal society life. Therefore, society obeys rules, including the rule of law as a series of standards for their behavior (Santoso,2008:21). If the laws created by the state are no longer able to regulate their interests and provide a sense of justice, then society will try to form new laws or sue the state. This is the reason why someone obeys the law because of the interest factor. A person obeys the law because he feels that his interests are being met.

People whose interests have been fulfilled by laws that made by the state feel that the state has carried out their aspirations in order to provide protection in the form of the value of justice. The existence of laws made by the state can be used as a guide in behaving (Bachriadi, 1997:43).

The law made by the state which is a representative in giving the aspirations of the society as has been made in the society agreement which aims to provide justice. However, in practice, the law made by the power holders does not provide legal protection for the society.

Various legal facts show the existence of power possessed by the state which does not aim to provide justice for society, whereas as it is known that the state is given power by the society on the basis of an agreement (social contract) in order to provide legal protection in the form of justice, one of them is reflected in the case of farmer mistreatment in Mesuji, Lampung due to seizure of land. Because the society feels that they do not get maximum justice as the goal of law in legal philosophy, so then the society can reclaim the power they have given to the authority (Tukgali, 2010:21). As for the basis used by the community in reclaiming the power they have given to the authority, because in the concept of "pactum subjectionis", society has formed an agreement as to who deserves to hold power. After the agreement is made, the powers given to the state are legitimated by using social facts and laws. 
The state, in exercising its power, must pay attention to the interests of its people, which aim to provide justice and prosperity. In the agreement made by the society in choosing the ruler, there must be legitimacy or it is believed by the society that they are worthy to hold that power. In historical development there are three forms of legitimacy as quoted by Frans Magnis Suseno:

1. Religious legitimacy is the legitimacy of who holds power that is directly representative of God on earth.

2. Elitist legitimacy is legitimacy where the power holders are only a few people or a group of people who have special skills to lead.

3. Democratic legitimacy is a legitimacy where the power holders must provide protection to the community in a way that the people can give their aspirations.

Based on the types of legitimacy above, then democratic legitimacy is the main basis for people who feel that their interests are not fulfilled to reclaim the power they have given to the holders of power. In the case of land disputes which resulted in persecution of farmers in Mesuji, Lampung shows that people who feel their interests are unprotected can file demands on the state. Apart from this case, There are still many cases of land disputes indicating that the legal regulations made by the state are not maximal in order to protect the interests of their people, This is reinforced by the large number of people who come to the people's representative building to demand a resolution of conflicts over land.

The main basis for society to sue the state because the state derives power from society and based on agreements made when the state cannot provide maximum legal protection in giving their aspirations, society can claim back to the state the power that they have given (Lubis, 2008:87). For society, good power holders must be able to provide maximum legal protection, which places common interests above individual interests.

The case above shows that the government's policy in maintaining and accelerating the plantation sector is to enlarge the creation of an unequal land tenure structure in Indonesia, the state only prioritizes personal interests not the interests of the society as applicable in the society agreement (contract social). This is reinforced by legal facts which state that out of 3.80 million hectares of large plantation areas, $85.80 \%$ of them are land with the status of state land. The control is granted to plantation companies, either in the form of Business Use Rights, Building Use Rights, Ownership Rights, Use Rights or formal recognition rights. This shows that the state does not provide the maximum opportunity for people to own land, which results in the issue of land designation of the state is often as the beginning of conflict between plantation parties or plantation concessionaires and the people who have long controlled the land, because according to the records of the Central Bureau of Statistics, $82.87 \%$ of the country's land is given its control to the plantation in form of Business Use Rights. Supposedly, the issue of granting land rights to legal entities must still provide opportunities for future generations to be able to access plantation land, because the right to access plantation land is the right to access land in order to take advantage of the land to meet the necessities of life for humans and their families is a human right guaranteed by the 1945 Constitution and must be implemented by the state or government. 
The practice of controlling the right to control the state, which states that all land in Indonesia is owned by the state, raises an indication of the state's partiality for big companies. This is considered contrary to the values of justice and human rights in the economic sector as stipulated in the 1945 Constitution and the objectives or the purpose of the Basic Agrarian Principles (UUPA), the utilization and use of land or agrarian for the greatest possible prosperity of the people.

According to Oalan Sitorus, the state authority in the land sector as referred to in Article 2 paragraph 2 of the Basic Agrarian Principles (UUPA) is the delegation of the nation's duties to regulate and lead the use of collective land which is a national asset. The right to control the state is the public authority's delegation from the the nation's rights. Consequently, this authority is only public. The purpose of the right to control the state is contained in Article 2 paragraph 3 of the Basic Agrarian Principles (UUPA), that is to achieve the greatest prosperity of the people in terms of happiness, prosperity, and independence in society and Indonesian law states that an independent, sovereign, fair and prosperous. In fact, the land that controlled by the state has more rights given to plantation companies arbitrarily, so in effect the regime that has been in power has reimposed the principle of domein verklaring (the principle of the state owning a number of lands or the principle of land owned by the state). With this principle, the state, precisely as a ruling regime, can abandon the interests of the people to achieve its own interests. In various provisions of laws and regulations, it can be found that there is excessive legal protection given by the state to plantation companies compared to communities. In the provisions of Article 30 paragraph 1 of Law Number 25 of 2007 concerning Investment, it states that "the government and / or local governments guarantee business certainty and security for the implementation of investment" and Article 20 of Law Number 18 Year 2004 concerning Plantation states that "plantation business actors carry out security in the plantation business under coordination by security forces and may involve assistance from the surrounding community". This shows an excessive part of the state siding with companies and becomes a means of illegal legal protection by becoming the public as the injured party (Asmawati,2004:11).

The legal protection provided by the state is excessive by putting aside the interests of the community, indirectly the state is considered to have abused power. This is also considered to be contrary to the concept of legal philosophy which states that in legal philosophy, law aims to get justice that leads to prosperity. Justice is a balance between personal interests and common interests, so that in the end the ultimate goal, prosperity, justice and happiness for all its people are achieved (Wowor, 2014:44)

Justice is one of the basic principles put down by the Basic Agrarian Principles in the context of utilization the agrarian sector for the prosperity of the people by placing national interests above individual interests, although that does not mean that the interests of certain individuals or groups can be simply sacrificed for the public interest.

According to Erich Jacoby, many people do not realize that what they are facing now is a new capitalism that was raised due to the various activities of the Trans National Corporation (TNC). In practice, this institutional adjustment is not "compatible" with the target and calculations 
of TNC's business that implementing technology transfer. Institutional adjustments have benefited TNC and still have not benefited the people. This is considered contrary to the target of agrarian reform, that is equal distribution of income and social justice as well as being integrated into all development policies.

John Powelson and Richard Stock edited a book entitled "The Peasant Betrayed" (the farmer betrayed) (Hanifa, 2016:32). According to them, the implementation of agrarian development in the 20th century, both socialist and capitalist styles, still has not succeeded in changing the position of farmers and lower-class society in general. Today almost all agrarian reform is based on the generosity of the government, so that once the government carries out its duties solely for the sake of its interests, the positive results that have been achieved by agrarian reform will be washed-up.

Various kinds of land dispute cases that have spread everywhere are evidence that agrarian problems, especially regarding land disputes, one of which is the case of mistreatment of farmers in Mesuji, Lampung. In the settlement process, the state still tends to side with big companies by ignoring the laws and regulations in the land sector which aim to uphold the value of justice for society.

The element of power holder is an important thing in the use of the power it has, according to the will of the community. Therefore, in addition to the necessity of having a law as a barrier, other elements that are possessed by those in power are also needed, such as an honest character and a high sense of community service.

According to Mahfud MD, legal reasons are a reflection of power holders or are identical to power by quoting Dahrendorf's opinion, he noted that there are six characteristics of dominant groups or groups of political power holders, they are:

1. the number is smaller than the number of groups that get controlled;

2. has the advantage of special wealth to maintain its dominance in the form of material, intellectual and moral respect;

3. in conflict it is always better organized than the group to be subdued;

4. the ruling class only consists of people who hold dominant positions in politics, so that the ruling elite is defined as the ruling elite in the political field;

5. the ruling class always tries to monopolize and pass on its political power to its own class / group;

6. there is a reduction in social change to changes in the composition of the ruling class.

Power is exercised (exercise of power) through clear signs. This is often called manifest power. But sometimes there are no signs, for example in what Carl Friedrich calls the rule of anticipated reactions. The essence of power is the right to impose sanctions. There are different ways to exercise power. The most effective effort is physical violence (force). Power can also be exercised through coercion, that is through the threat of sanctions. One effort that is slightly lenient is through persuasion, the process of convincing, arguing, or appointing an expert's opinion (expert advice). In addition, it can be used in other ways, by not saying a fine, but giving rewards or intensive, rewarding, or compensation. 
The relationship between law and power that is related to a phenomenon that occurs in society, in the case of mistreatment of farmers in Mesuji, Lampung, legal philosophy has the duty to formulate political ideals in terms of justice and legal order. Philosophy is usually seen as the main of science or general science. Pythagoras said that philosophy is the love of wisdom because the words "philein" (Greek) and sophia mean love of wisdom. Philosophy is sought for wisdom and wisdom is sought. Philosophy is the principle of existence and which presumes the most important reality. Philosophy is about science, the criticism and systematic of knowledge, the inference of empirical science, the teaching of rational reasoning, and so on.

The relationship between law and power that occurs in the case of farmer mistreatment in Mesuji, Lampung is that if you use a philosophical solution, it is hoped that it can provide the fairest justice for the community this is because in legal philosophy, law aims to provide justice which results in welfare. As it is known formally the government's authority to regulate the land sector grows and takes root from Article 33 paragraph 3 of the 1945 Constitution, then it is transmitted into Law Number 5 of 1960 concerning the Basic Agrarian Law, then spreads to various organic regulations in the form of Government Regulations, Decrees President, Presidential Regulation, and Regulations issued by heads of technical institutes in the land sector. Substantially, the government's authority in regulating the land sector, especially in legal traffic and land use, is based on the provision of Article 2 paragraph 2 of the Basic Agrarian Principles (UUPA). With these provisions, the government has been given juridical authority to make rules and regulations (bestemming) in the agrarian field in the form of land (execution) concerning the subject, object, and legal relationship between the subject and object as long as it concerns agrarian resources (Herwandi, 2010:90)

The development of investment law in the plantation sector should be directed towards realizing a harmonious plantation investment legal system based on Pancasila and the 1945 Constitution, so that people who have a high legal awareness and culture are created in the context of realizing harmonious investment regulations in the plantation sector, without having to make the community as a weak party as a victim of the power held by the state.

In such circumstances, the state should be obliged to continue to improve laws and regulations that do not take sides with the interested parties and must respect the human rights of the people as land owners, so that the legal function as described in the philosophy of law can be created, that is fulfilling a sense of justice that results in welfare for all societies (Pahlefi: 2014,:66). The regulations made by the state must be able to reflect the value of justice for all society. Land ownership is a human right protected by national and international law (Brotosoelarno,1997:21). In international law, protection of property rights is regulated in the DUHAM (General Declaration of Human Rights) Article 17 paragraph 1, Article 17 paragraph 2, Article 25 paragraph 1 , and Article 30. In national law, legal protection of property rights is regulated in the 1945 Constitution Article $28 \mathrm{H}$ paragraph 4 and Law Number 39 Year 1999 concerning Human Rights. It is because one legal task is to provide protection for the people in order to create discipline, justice and legal certainty (Sirajuddin:2013:21) 


\section{Conclusion}

Based on the description above, three conclusions can be drawn. First, power is a conception of social relations between two parties or two institutions that are mutually influencing, dominant or exploitativeSecond, the essence of law can be viewed from the point of view of the authority that forms it, its substance and its working power in regulating society. Third, the dialectic of law and power creates two relationship patterns, law is identical with power and law is not the same as power. The pattern of legal relations is identical with power, which reflects itself in the form of sovereignty, authority, competence and rights.

\section{References}

Abdurrahman. (1978). Aneka masalah hukum agraria dalam pembangunan di Indonesia "Seri hukum agraria II", Alumni.

Asmawati, "Mediasi Salah Satu Cara dalam Penyelesaian Sengketa Pertanahan", Jurnal Imu Hukum, (Maret 2004)

Bachriadi, Dianto., Faryadi, Erpan \& Setiawan, Bonnie. (1997). Reformasi Agaria "Perubahan Politik, Sengketa, dan Agenda Pembaharuan Agraria di Indonesia, Konsorsium Pembaharuan Agraria dan Fakultas Ekonomi Universitas Indonesia.

Brotosoelarno, Soelarman. Aspek Teknis dan Yuridis Pendaftaran Tanah Berdasarkan PP Nomor 24 Tahun 1997”, (b) (makalah disampaikan pada Seminar Nasional Kebijakan Baru Pendaftaran Tanah dan PajakPajak Tanah Terkait : Suatu Proses Sosialisasi dan Tantangannya, Yogyakarta.

Chomziah, Ali Achmad. (2004). Hukum Agraria Pertanahan Indonesia (1th ed.). Prestasi Pustaka Publisher.

Hanifah, Mardalena. (2016). Kajian yuridis: Mediasi sebagai alternatif penyelesaian sengketa perdata di pengadilan. ADHAPER Jurnal Hukum Acara Perdata, 2(1),1-13. 10.36913/jhaper.v2i1.21.

Herwandi. (2010). Peranan Kantor Pertanahan dalam Rangka Menyelesaikan Sengketa Tanah Secara Mediasi di Kantor Pertanahan Jakarta Utara. Tesis. Universitas Diponegoro Semarang.

Lubis, Mhd. Yamin \& Lubis, Abd. Rahim. (2008). Hukum Pendaftaran Tanah, CV. Mandar Maju.

Pahlefi. (2014). Analisis bentuk-bentuk sengketa hukum atas tanah menurut peraturan perundang-undangan di bidang agrarian. Majalah Hukum Forum Akademika, Vol. 25.

Purbacaraka, Purnadi \& Soekanto, Soerjono. (1994). Renungan tentang Filsafat Hukum, PT. Raja Grafindo Persada.

Rasyidi, Lili \& Rasjidi, Ira Thania. (2007). Pengantar Filsafat Hukum, CV.Mandar Maju.

Rasyidi, Lili. (1990). Dasar-Dasar Filsafat Hukum. Citra Aditya Bakti.

Sirajuddin. (2013). Format kekuasaan kehakiman dalam perubahan lanjutan konstitusi. Jurnal Konstitusi Fakultas Hukum Universitas Andalas, 20(2).

Soekanto, Soerjono. (1980). Pokok-Pokok Sosisologi Hukum, Rajawali Pers.

Soekanto, Soerjono. (2006). Sosiologi Suatu Pengantar, PT. Raja Grafindo Persada. 
Soetiksno. (2008). Filsafat Hukum, Bagian I, PT.Pradnya Paramita.

Santoso, Urip. (2008). Hukum Agraria dan Hak-Hak Atas Tanah, Kencana.

Tukgali, Lieke Lianadevi. (2010). Fungsi Sosial Hak Atas Tanah dalam Pengadaan Tanah untuk Kepentingan Umum. Kertasputih Communication.

Wowor, Fingli A. (2014) Fungsi badan pertanahan nasional terhadap penyelesaian sengketa tanah, Lex Privatum, 2(2), 95-104. 
= 